\title{
Current Research: Organic Residues on Engraved Vessels from Ancestral Caddo Sites in East Texas
}

Timothy K. Perttula

Heritage Research Center, Stephen F. Austin State University

Follow this and additional works at: https://scholarworks.sfasu.edu/ita

Part of the American Material Culture Commons, Archaeological Anthropology Commons, Environmental Studies Commons, Other American Studies Commons, Other Arts and Humanities Commons, Other History of Art, Architecture, and Archaeology Commons, and the United States History Commons

Tell us how this article helped you.

This Article is brought to you for free and open access by the Center for Regional Heritage Research at SFA ScholarWorks. It has been accepted for inclusion in Index of Texas Archaeology: Open Access Gray Literature from the Lone Star State by an authorized editor of SFA ScholarWorks. For more information, please contact cdsscholarworks@sfasu.edu. 
Current Research: Organic Residues on Engraved Vessels from Ancestral Caddo Sites in East Texas

\section{Creative Commons License}

(c) (1) (8)

This work is licensed under a Creative Commons Attribution-NonCommercial 4.0 International License 


\title{
Current Research: Organic Residues on Engraved Vessels from Ancestral Caddo Sites in East Texas
}

\author{
Timothy K. Perttula
}

Archeological \& Environmental Consultants, LLC

In the course of recently documenting ancestral Caddo ceramic vessels from sites dating to Late Caddo period Titus phase contexts (ca. A.D. 1430-1680) in East Texas, specifically on sites in the Big Cypress Creek and Sabine River basins, I have encountered a significant number (ca. 9.6 percent) of more than 1790 engraved fine ware vessels that have an exterior organic residue (Table 1), including carinated bowls, compound bowls, jars, bowls, and even bottles. In some cases, the exterior residue on certain carinated bowls and compound bowls is so thick that the engraved design is obscured and almost completely covered with the organic residue (Figure 1a-c). If engraved fine wares from ancestral Caddo sites were used in daily life for the serving of foods and liquids, how did they accumulate an exterior carbonized residue by the time they were placed in burials as funerary offerings?

The exterior residue on Titus phase fine ware vessels appears to be the product of soot deposition from the smoke produced in a wood or grass fire (Skibo 2015:190; see also Skibo 1992:152-173). Skibo (2015:190) notes that this "type of soot is more permanently affixed to the ceramic surface because it contains resin droplets, which are drawn up with the rising smoke and are solidified once they come in contact with cooler surfaces. One the resin cools, it can produce a hard, waterproof soot layer that is very resistant to breakdown." Such soot can be deposited if vessel surfaces are less than 400 degrees C, most likely because of the presence of liquids in a vessel (Skibo 2015:191). Skibo's examination (September 11, 2018 personal communication) of Figure 1b-c notes that the residue looks "like classic exterior soot from being placed over the fire. The one pot has oxidation on the base and soot up to the rim [Figure 1b], which is very common. When a pot is right next to the flame, soot will not accumulate, but it will on the sides." He also noted that "soot like this can be added to a vessel in just one... episode."

\begin{tabular}{|c|c|c|c|}
\hline Site & No. of fine ware vessels & No. with organic residue & Percent \\
\hline Hinton Coll.* & 220 & 18 & 8.2 \\
\hline $41 \mathrm{CP} 5$ & 138 & 15 & 10.9 \\
\hline $41 \mathrm{CP} 12$ & 187 & 19 & 10.2 \\
\hline 41CP304 & 68 & 10 & 14.7 \\
\hline 41FK2 & 39 & 2 & 5.1 \\
\hline 41FK4 & 57 & 4 & 7.0 \\
\hline $41 \mathrm{HS} 3$ & 326 & 4 & 1.2 \\
\hline 41HS15 & 81 & 9 & 11.1 \\
\hline 41MX2 & 57 & 9 & 15.8 \\
\hline 41TT6 & 52 & 8 & 15.4 \\
\hline 41TT7 & 165 & 29 & 17.6 \\
\hline 41TT550 & 46 & 13 & 28.3 \\
\hline 41UR2 & 108 & 10 & 9.3 \\
\hline 41UR315 & 95 & 4 & 4.2 \\
\hline 41UR317 & 67 & 9 & 13.4 \\
\hline 41UR318 & 38 & 4 & 10.5 \\
\hline 41UR326 & 48 & 6 & 12.5 \\
\hline Totals & 1792 & 173 & 9.6 \\
\hline \multicolumn{4}{|c|}{$\begin{array}{l}\text { * From a variety of sites in Camp and Titus counties, Texas (Perttula et al. 2012a) } \\
\text { Source: 41CP5 (Perttula et al. 2010a); 41CP12 (Perttula et al. 2010b); 41CP304 (Perttula 2005) } \\
\text { 41FK2 (Perttula 2019); 41FK4 (Perttula 2019); 41HS3 (Perttula 2018); 41HS15 (Fields and } \\
\text { Gadus 2012); 41MX2 (Perttula 2019); 41TT6 (Fields et al. 2014; Eloise Gadus, September } 201 \\
\text { personal communication); 41TT7 (Perttula 2019); 41TT550 (Perttula et al. 1998); 41UR2 } \\
\text { (Perttula 2019); 41UR315 (Perttula et al. 2012b); 41UR317 (Perttula et al. 2012c); 41UR318 } \\
\text { (Perttula et al. 2012c); 41UR326 (Perttula et al. 2012c) }\end{array}$} \\
\hline
\end{tabular}

Table 1. Proportion of engraved vessels with organic residues from a sample of Titus phase sites.

To account for the soot and exterior organic residues on a significant proportion of engraved fine ware vessels (principally carinated bowls) in Late Caddo period Titus phase burial features, I suggest that these vessels (and their contents) were smoked in fires, or suspended over fires, that had been placed at one end of the grave during ancestral Caddo mortuary rituals. Carter (1995:128) has noted that in Caddo mortuary rituals, "[s]omeone in the family kept a fire burning at the east end of the grave for the six days a spirit stayed before starting on its way. All personal possessions, such as clothes owned by the one who had died, were hung on a pole set beside the fire to be bathed in its smoke." These Titus phase engraved vessels were bathed in such a smoke. Both grass and cedar twigs were used to create the bathing smoke (Carter 1995:138-139; Espinosa 1927:163-164).

The age, frequency, and distribution of engraved fine ware vessels with organic residues from being "smoked" should be systematically determined in other areas of East Texas, as well as in other parts 


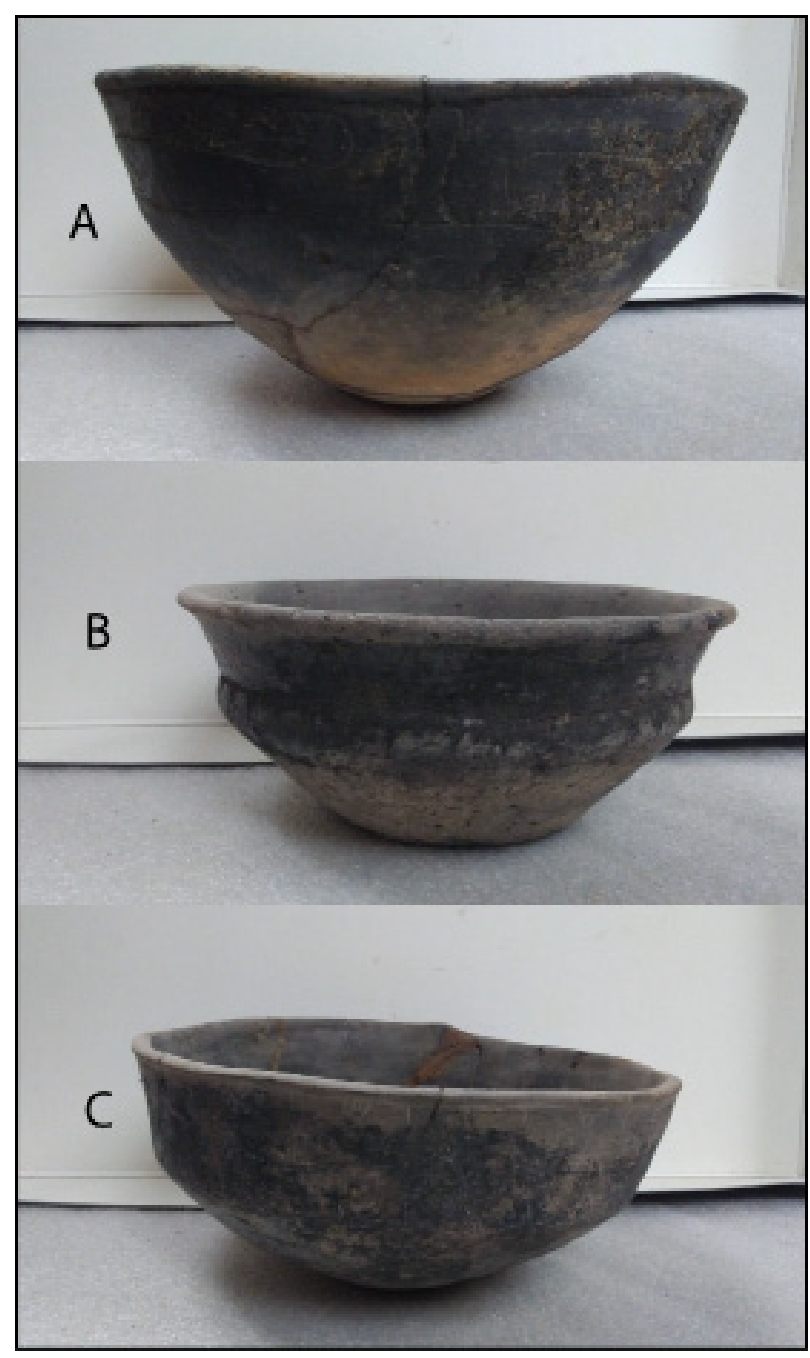

Figure 1. Examples of engraved Titus phase vessels with a thick charred organic residue on their exterior surfaces: a, Vessel 13, Joe Justiss site (41MX2); b, Vessel 74, Russell Bros. site (41TT7); c, Vessel 91, Russell Bros. site (41TT7).

of the Caddo area. Recent communications with Ann Early, Pete Gregory, Jeff Girard, and Duncan McKinnon indicate that engraved vessels of any age with organic residues are very rare to absent in ancestral Caddo vessel assemblages from the Ouachita and Red River basins in Southwest Arkansas and assemblages in Northwest Louisiana. This indicates that the behaviors by Caddo peoples in parts of East Texas after ca. A.D. 1430 (and perhaps before that time as well) differed from other Caddo communities in likely grave side rituals that produced the exterior residue on vessels that were placed as funerary offerings in ancestral Caddo burials. This diversity in mortuary behavior warrants further evaluation and consideration as part of developing a better understanding of the history and character of ancestral Caddo mortuary traditions.

Finally, it is hoped that samples of the charred residue on a few engraved Titus phase vessels with thick exterior residue can be analyzed. Such samples of the charred materials could be subjected to lipid analysis, gas chromatography/mass spectroscopy (see Evershed 2000), and phytolith and starch analysis, to determine what plants were burned and smoked to produce the soot on the vessels.

\section{Acknowledgments}

I thank those individuals that talked, corresponded, or shared information with me about exterior residues on Caddo fine ware vessels. They include Steve Black, Ann M. Early, Eloise Gadus, Jeff Girard, Pete Gregory, John P. Hart, Duncan P. McKinnon, and James M. Skibo.

\section{References Cited}

Carter, C. E.

1995 Caddo Indians: Where We Come From. University of Oklahoma Press, Norman.

Espinosa, I. F. de

1927 Descriptions of the Tejas or Asinai Indians, 16911722. Translated by M. A. Hatcher. Southwestern Historical Quarterly 31:150-180.

Evershed, R. P.

2000 Biomolecular analysis by organic mass spectrometry. In Modern Analytical Methods in Art and Archaeology, edited by E. Ciliberto and G. Spoto, pp. 177-239. John Wiley \& Sons, New York.

Fields, R. C., and E. F. Gadus (editors)

2012 Archeology of the Nadaco Caddo: The View from the Pine Tree Mound Site (41HS15), Harrison County, Texas. 2 Vols. Reports of Investigations No. 164. Prewitt and Associates, Inc., Austin. 
Fields, R. C., V. L. Hatfield, D. Burden, E. F. Gadus, M. C. Wilder, and K. W. Kibler

2014 Testing and Data Recovery Excavations at 11 Native American Archeological Sites along the U.S. Highway 271 Mount Pleasant Relief Route, Titus County, Texas. 2 Vols. Reports of Investigations No. 168. Prewitt and Associates, Inc., Austin.

Perttula, T. K.

2018 Ceramic Vessels and Other Funerary Objects in the H. R. Taylor (41HS3) Cemetery, Harrison County, Texas. Special Publication No. 46. Friends of Northeast Texas Archaeology, Austin and Pittsburg.

2019 A Study of Ancestral Caddo Ceramic Vessels from Titus Phase Sites in Camp, Franklin, Harrison, Marion, Morris, Titus, and Upshur Counties in East Texas. Special Publication No. 52. Friends of Northeast Texas Archaeology, Austin and Pittsburg.

Perttula, T. K. (editor)

2005 Archeological Investigations at the Pilgrim's Pride Site (41CP304), a Titus Phase Community in the Big Cypress Creek Basin, Camp County, Texas. Report of Investigations No. 30, 2 Vols. Archeological \& Environmental Consultants, LLC, Austin.

Perttula, T. K., P. S. Marceaux, and B. Nelson 2012a Study of the Margaret Hinton Collection of Pottery Vessels from Northeast Texas Caddo Cemeteries. Archeological \& Environmental Consultants, LLC, Austin.

Perttula, T. K., B. Nelson, and M. Walters

2012b Caddo Archaeology at the Henry Spencer Site (41UR315) in the Little Cypress Creek Basin of East Texas. Special Publication No. 20. Friends of Northeast Texas Archaeology, Pittsburg and Austin.
Perttula, T. K., M. Walters, and B. Nelson

2010a Caddo Pottery Vessels and Pipes from Sites in the Big Cypress, Sulphur, Neches-Angelina, and Middle Sabine River Basins in the Turner and Johns Collections, Camp, Cass, Cherokee, Harrison, Morris, Titus, and Upshur Counties, Texas and Sabine Parish, Louisiana. Special Publication No. 10. Friends of Northeast Texas Archaeology, Austin and Pittsburg.

2010b Caddo Pottery Vessels and Pipes from the Johns Site (41CP12) in the Big Cypress Creek Basin in the Turner and Johns Collections, Camp County, Texas. Special Publication No. 11. Friends of Northeast Texas Archaeology, Austin and Pittsburg.

2012c Little Cypress Creek Basin Archaeology: Six Late Caddo Period Cemeteries in Upshur County, Texas. Special Publication No. 22. Friends of Northeast Texas Archaeology, Austin and Pittsburg.

Perttula, T. K., M. Tate, H. Neff, J. W. Cogswell, M. D. Glascock, E. Skokan, S. Mulholland, R. Rogers, and B. Nelson

1998 Analysis of the Titus Phase Mortuary Assemblage at the Mockingbird Site Kahbakayammaahin" (41TT550). Document No. 970849. Espey, Huston \& Associates, Inc., Austin.

Skibo, J. M.

1992 Pottery Function: A Use-Alteration Perspective. Plenum Press, New York and London.

2015 Pottery Use-Alteration Analysis. In Use-Wear and Residue Analysis in Archaeology, edited by J. M. Marreiros, pp. 189-198. Manuals in Archaeological Method, Theory and Technique. DOI 10.1007/978-3-319-08257-8_10. 